\title{
THE CONTRIBUTION OF L. I. TEGAKO TO ANTHROPOLOGY OF BELARUS
}

\author{
Tatyana Hurbo \\ Department of Anthropology, Institute of History, National Academy of Sciences of Belarus \\ Minsk, Belarus
}

Summary. L.I. Tegako started her studies of anthropology in the middle of 1960 s when she received her research degree. The scope of her scientific interest included odontology and dermatoglyphics. For more than 40 years L.I. Tegako was a permanent supervisor of the group and later of the Anthropology department. From the beginning of 1970s Belarusian anthropologists started conducting complex anthropologic studies of the adult population of the republic in various parts of the country (anthropometry, anthroposcopy, dermatoglyphics, blood group factor). Comprehensive approach became the basis for studies of anthropogenic variety of local population on the territory of Belarus. In 1998 the team of anthropologists supervised by L.I. Tegako won a State Prize of the Republic of Belarus for the scope of work on the topic "Person and his biocultural adaptation". In 2000s the scope of L.I. Tegako's scientific interest included the determination of intersystemic correlations between dermatoglyphical and psychosomatic characteristics. During her academic career, L.I. Tegako published 17 monographs, 6 study guides, 11 brochures and 209 research papers. Lidiya Ivanovna worked at leading universities in the country; she had 7 students who completed PhD thesis. Since 1999 she worked as a professor of biology. L.I. Tegako deserves a credit for the organization of anthropological conferences in Minsk. She devoted a lot of attention to the international cooperation. As a result, L.I. Tegako contributed to the establishment of stable scientific and friendly ties with Serbian colleagues: Institute of History of the NAS of Belarus and Matica Srpska made a partnership agreement. This includes exchange of experience, scientific works, and realization of joint projects.

Key words: I. Tegako, anthropology, Belarus, dermatoglyphics, odontology, complex investigation.

In February 2015, the Belarusian anthropology suffered a great loss - L. I. Tegako, one of the founders of the Belarusian anthropology in the National Academy of Sciences of Belarus, died (Figure 1).

Lidiya - Ukrainian nationality, was born on February 21, 1937 in the village of Kompaniivka, Kirovohrad region of Ukraine. After leaving school in 1954 she entered Lviv Medical Institute. During her studies, Lidiya met Vladimir Vasilyevich Tegako, who studied at the Polytechnic Institute at the time. They got married. Vladimir Vasilyevich was sent to work in Minsk, where he went with his entire family. So Lidiya was in Minsk. In 1960 she graduated from the Minsk State Medical Institute, pediatric faculty. After graduation, Lidiya Ivanovna worked as a pediatrician in the First Clinical Hospital of Minsk from 1960 to 1965 (Figure 2).

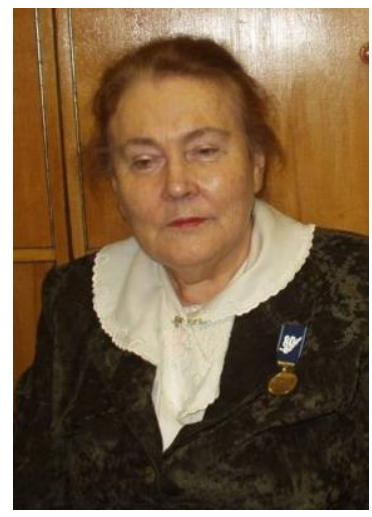

Figure 1. L.I. Tegako (21.02.1937- 10.02.2015) 
February 1965 saw the beginning of postgraduate training programme with a degree in anthropology at the Institute of Art, Ethnography and Folklore of the Academy of Sciences of the BSSR. The first students to graduate were L. Tegako, A. Mikulich, I. Salivon (Figure 3). In the mid1960s, L. Tegako began research on ethnic dermatoglyphics and odontology in Belarus for the very first time. Her teacher was one of the leading anthropologists in Russia - V.P. Alekseev. Dissertation of L. I. Tegako was «Anthropological data to the ethnogenesis of the Belarusian people (dermatoglyphics and odonthology)» (Тегако, 1970). She collected a great deal of data on the handprints of Belarusians from different regions: Eastern and Western Polesie, Poozerye, Belarusians from Minsk and Mogilev regions, Belarusian Tatars, Belarusians from Russia's Smolensk and Bryansk regions, Poles, Lithuanians, and Latvians. Totally 2346 people were studied according to dermatoglyphic characteristics, and 1134 people - according to odontologic characteristics. Data were analyzed from the

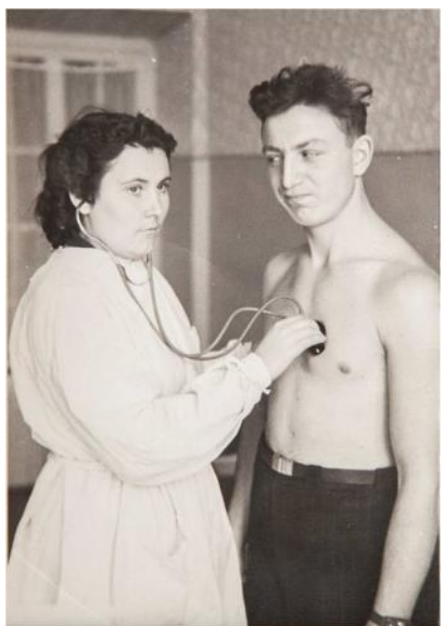

Figure 2. Lidiya Ivanovna doctor-pediatrician perspective of race.

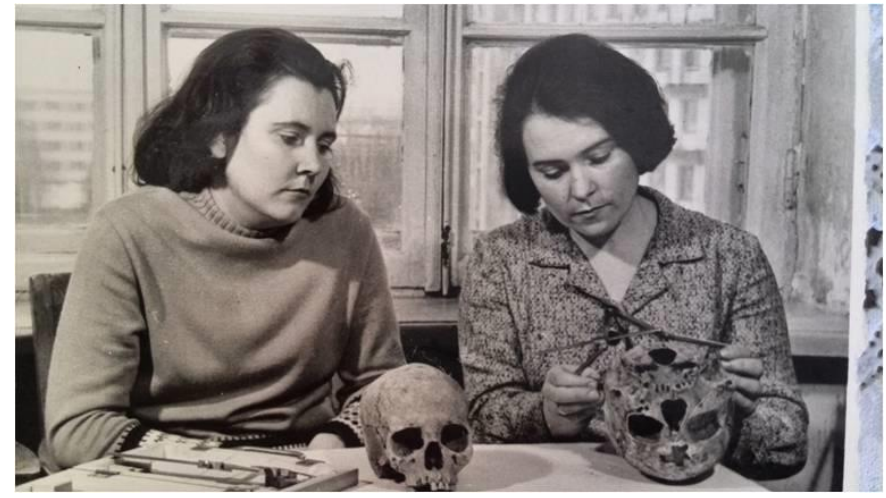

Figure 3. 1965-1969: postgraduate studies. L.I. Tegako and I.I. Salivon.

As a result of the research on dermatoglyphics L. I. Tegako pointed out that in general Belarusians manage to stay within variations which are typical for Caucasian race according to allocation of dermatoglyphic characteristics. The phenomenon was figuratively named «mongoloidness», there was an increase in the direction of the South-West to the North-East according to important dermatoglyphic characteristics.

Upon a between-group analysis of odontologic characteristics the author indicates that Belarusians of the Western Polesie stand out among Belarusian territorial groups as they tend more strongly to «caucasianness». An increase in the number of «mongoloidness» phenomena is shown according to some characteristics to the North-East and the North-West from the territory of the West Palesia. Relations between groups according to the studied characteristics can be considered as historically developed. This is shown by discordance of correlations in groups and between groups according to odontologic characteristics. 
After graduating from school and completing her $\mathrm{PhD}$ thesis L. I. Tegako worked first as a junior researcher, then - senior and leading researcher of the Institute of Arts, Ethnography and Folklore of the of the Academy of Sciences of the BSSR from 1969 to 1990.

Lidiya Ivanovna led the organization of complex anthropological research in the Republic for many years. In 1971 a new stage of research began under the supervision of L.I. Tegako - introduction into practice of the complex program of adult population of the BSSR that included anthropometric, dermatoglyphic, odontologic, isoserological characteristics with simultaneous analysis of dermographic indices and other social factors showing influence on anthropological features of studied population. In 1980s anthropological studies were carried out within the project № 12 «Interactions between environmental transformations and adaptable, demographic and genetic structure of human population» of UNESCO program «Man and Biosphere». Under the supervision of L. I. Tegako multipurpose expeditions were carried out on the territory of Belarusian Polesye and Poozerye, in the central region of the republic.

In 1980s a comprehensive study of child population of Belarus was launched. A broad comprehensive programme of research of children included numerous aspects: anthropometric, dermatoglyphic, some demographic ones. Moreover, the programme included the visual identification of somatotypes, measurements of functional parameters and heart rate, determination of the indicator of skeletal muscle tone, symmetry tests, psychological tests, as well as questionnaires on social aspects (Marfina, 2015).

Belarusian anthropologists under the leadership of L. I. Tegako studied many regions of the republic, more than 20 expeditions were conducted outside the republic. L. I. Tegako took part in the expeditions of the Research Institute and Museum of Anthropology from Moscow State University. The purpose of these expeditions was to study the Chukchi, Eskimos, Kazakhs and Khakas populations.

Lidiya Ivanovna completed doctoral dissertation in Novosibirsk (Russia) in 1990, the topic was «The organizing structure of dermatoglyphic patterns and population variability (based on the study of the population of Belarus) » (Тегако, 1990). Information on racial dermatoglyphics of Belarusians, gender and bilateral changeability, as well as changes of signs in men and women, level of integration of finger and palmar patterns, dispersion parts of dermatoglyphics were collected and summarized for the first time (Тегако, 1989).

The work was the first attempt of a diversified multi-dimensional analysis of dermatoglyphic characteristics involving numerous materials about population. Data on 50 local groups were summoned up, 30 of them are from the territory of the BSSR. The study of skin relief characteristics in Belarusian groups showed that their frequency did not go beyond changeability typical for European people.

Comparison of Belarusian groups according to several racial dermatoglyphic characteristics revealed their high local changeability, i.e. changeability on the population level. Absence of rapid discretion in geographic changeability of characteristics showed domination of population integration processes on this territory.

L. I. Tegako indicated that regional changeability makes up 3,5\% of all changeability of dermatoglyphic characteristics on the territory of the BSSR that proved closeness of Belarusian groups. On the level of local populations, whorls and delta indexes are gaining more and more importance. Discrimination of characteristics in geographically separated groups depends on the changeability in these groups. Age factors play an important role in changeability on the population level.

For more than 40 years L.I. Tegako was a permanent supervisor of the group and then of the anthropology department (Figure 4). In 1990-2013 she was a head of the Department of Anthropology and Ecology, first - in the Institute of Arts, Ethnography and Folklore, from 2008 - in the Institute of History of the National Academy of Sciences of Belarus. 


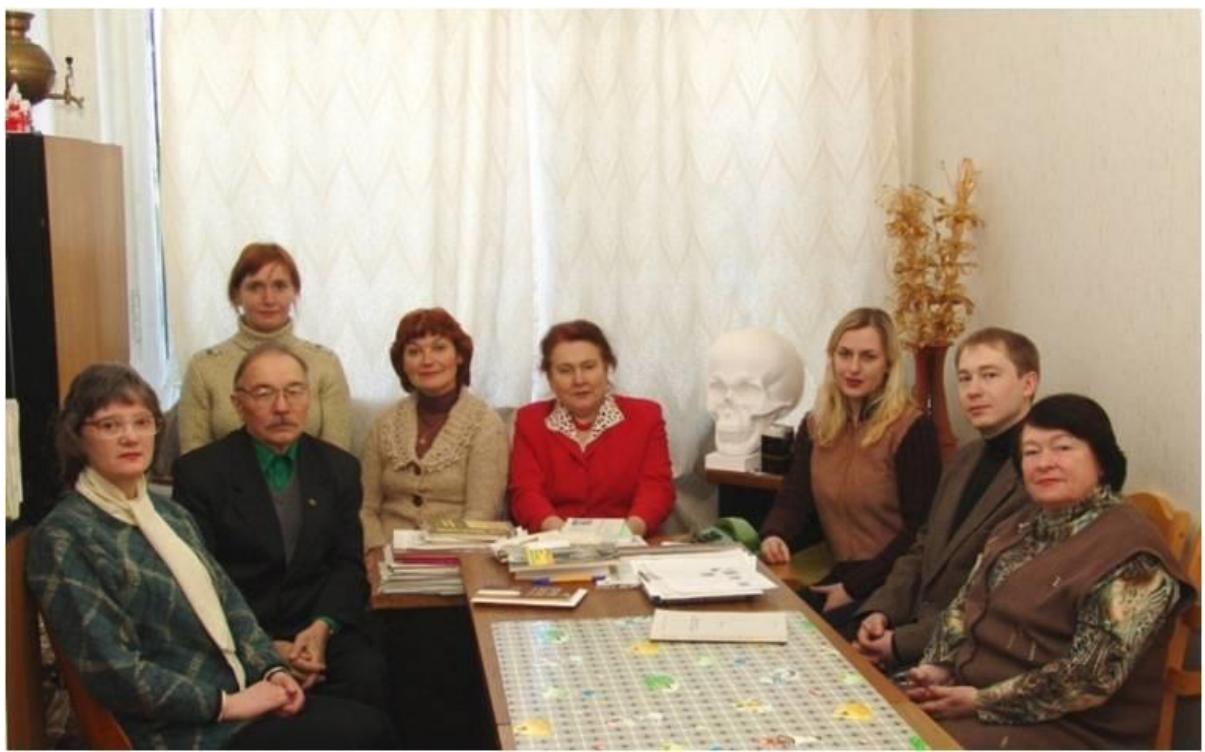

Figure 4. Department of Anthropology and Ecology of the Institute of Arts, Ethnography and Folklore of the National Academy of Sciences of Belarus (2007)

During her academic career, L. I. Tegako published 17 monographs, 6 study guides, 11 brochures and more than 200 research papers.

During the last years of her life, Lidia Ivanovna focused on dermatoglyphic research, in which she was greatly interested and which, in her opinion, represented the direction of somatopsychology. L.I. Tegako paid attention to the characteristics that were important for the processes of social adaptation and behavior regulation. Her latest work is the book «Dermatoglyphics in modern scientific knowledge of man» (co-authored with E. D. Kobyliansky), published in February 2015 (Тегако, Кобылянский, 2015). This work combines the results of multifold researches, held by authors during the long period of time in different populations according to different programs, including racial peculiarities in dermatoglyphics of Belarusians, its genetic aspects, connections of dermatoglyphics with human psychological traits.

Assuming that skin and central nervous system structures come from one germ layer ectoderm and their formation takes place in the same time interval, correlations between dermatoglyphic signs and psychological indices were analyzed. Complex studies which, along with studies of finger and palm patterns and psychological research used anthropometrics measuring of constitutional peculiarities of hand (palm's length and width, proportions of finger length to palm's length and width, proportion of finger phalanx to their length, finger index 2D/4D, etc.) were carried out.

Studies revealed high correlation between pattern types on the first and the fifth finger on the left hand, the second and the third finger on the right hand and irritability, as well as between the patterns on the right hand fifth finger and reactive aggressiveness. Moderate correlation level of such psychological characteristics as extraversion-introversion and emotional instability with pattern types on some fingers on the left and the right hands was revealed. To predict psychological features, based on dermatoglyphic markers, further definition of the most important dermatoglyphic markers, based on reliable correlations and use of different statistical methods is required. 
Lidiya Ivanovna contributed much to the methods used in teaching anthropology; she conveyed her experience and knowledge to further generations of scientists. She worked at leading universities of the country; she had 7 students who completed PhD thesis. Since 1999 she had worked as a professor of biology. For 14 years Lidiya Ivanovna had been the head of the Council for $\mathrm{PhD}$ thesis on anthropology which qualified anthropological personnel in Belarus, was the opponent for $\mathrm{PhD}$ and doctoral theses.

The communication with Lidiya Ivanovna for many has become a school of life.

A comparison of morphological and functional indicators in the development of children and adolescents from different regions of Belarus in pre and post Chernobyl periods allowed the identification of changes that indicated the strength of adaptation processes in all the regions of the republic. The results of this research were presented in six separate monographs published by the staff from the department from 1982 to 1996. In 1998 the team of anthropologists supervised by Lidiya Ivanovna won a State Prize of the Republic of Belarus for the scope of work on the topic «Person and his biocultural adaptation» (Марфина, 2015).

Lidiya Ivanovna received countless letters of thanks in her life. Probably the greatest joy or reward was the opportunity to do what she liked.

Lidiya Ivanovna deserves a credit for organization of anthropological conferences in Minsk. She paid a lot of attention to the international cooperation - with scientists from Russia, Poland, Serbia and Estonia.

For the first time Lidiya Ivanovna visited Serbia (Yugoslavia at that time) in 1974. Since then she tried to participate in annual congresses of Anthropological Society of Yugoslavia (Serbia) and regularly wrote articles.

As a result, L.I. Tegako contributed to the establishment of stable scientific and friendly ties with Serbian colleagues: Institute of History of the National Academy of Sciences of Belarus and Matica Srpska made a partnership agreement. This includes exchange of experience, scientific works, and realization of joint projects.

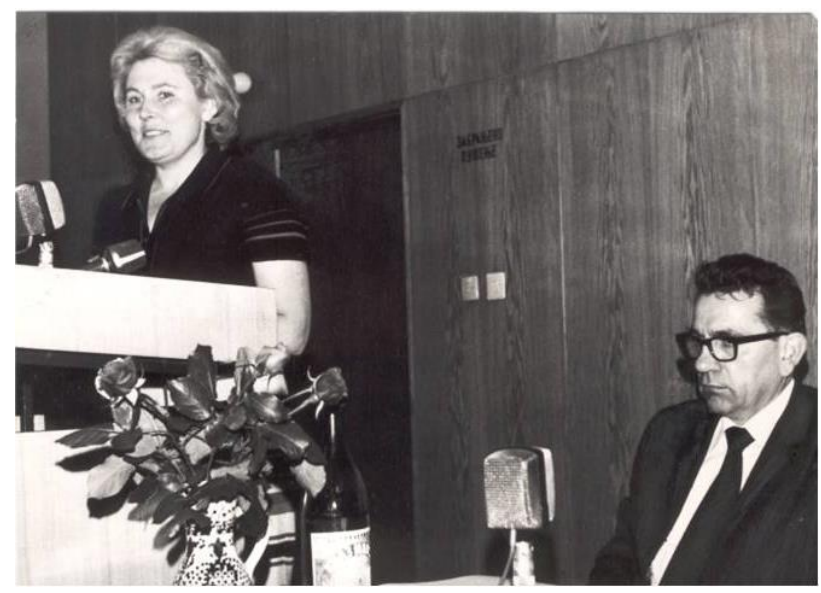

Figure 5. L.I. Tegako at the Congress of Anthropological society of Yugoslavia (1974)

The theme of the project «Changes of Morphofunctional Indicators of people in Belarus and Vojvodina (Serbia)». Obtained Results: new results for inter-ethnic comparisons of the genetic, morphological and functional parameters of the population, selected indicators of 
health status in a changing environment and globalization were obtained. A significant proximity on group factors of the blood system $\mathrm{AB} 0$ and $\mathrm{RH}$ between Belarusians and Serbs was marked. By morphological indicators, starting with the neonatal period and before the beginning of the definitive period, the differences were found: the population of Vojvodina (Serbia) had higher values of height, weight, other body sizes, subcutaneous adipose, comparing to the population of Belarus. These differences can be attributed to various anthropological types, formed in the process of historical development under the influence of adaptation to different habitats. The differences were marked in the temporal variability of the physical development of the child population. If at Belarusian children, the stabilization of growth processes is marked in the last decade, the processes of acceleration is not fixed, at Serbian children - acceleration continues. At the same time in both countries the gracilization of children was recorded - reduced chest circumference, body weight. These processes are connected, primarily, with the impact of the urban lifestyle, the urban microenvironment. Assessment of impact of certain biological and social factors on the health of the dental system of the Belarusian population and Vojvodina (Serbia) showed significant contribution of social factor in the improvement of dental health (presence of prevention programs, the level of education of parents, culture of food, etc.) for both countries.

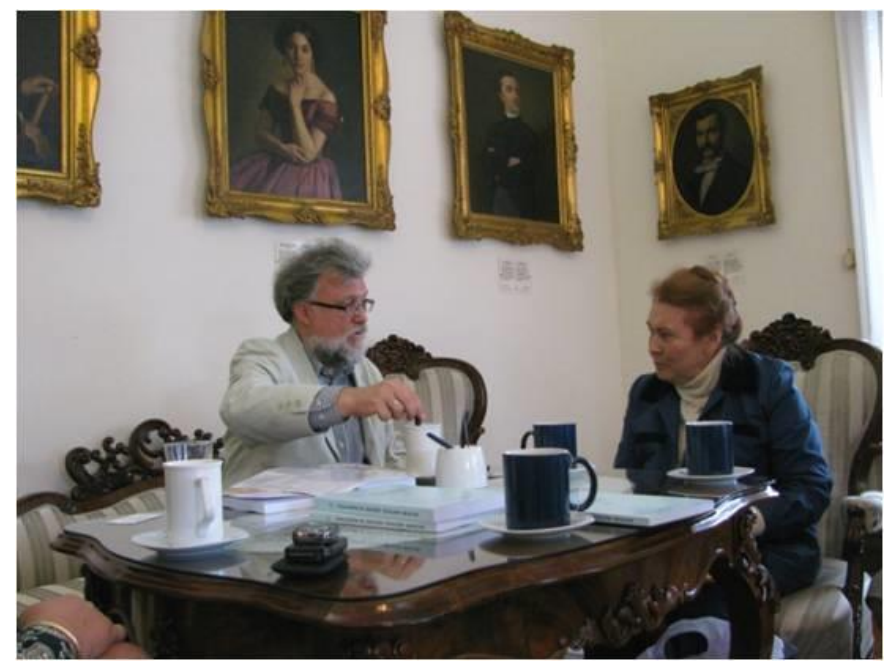

Figure 6. Lidiya Ivanovna in the Matica Srpska (2012)

Not only did she and her Serbian colleagues share common interest for science but also friendship and mutual affection. Having visited Serbia once, Lidia Ivanovna fell in love with it forever and carried her love and respect to this country and its people throughout her life.

Looking back on Lidiya Ivanovna's life, we regret that she did not live longer. Because she had many plans and a great desire to continue with her work. But, now, already having the whole picture of her life in mind, we can say that it was good. A Happy wife, mother of two daughters, grandmother of four grandchildren, Lidiya was both a successful scientist and organizer, a leader of an entire field of anthropology in the Republic of Belarus. Knowing the character of Lidiya Ivanovna, you can imagine her dissatisfaction and the fact that it made, but objectively, one can only admire and be inspired by her thoughts, ideas, and projects. 


\title{
References
}

Марфина О.В. 2015. История антропологических исследований в Беларуси. Минск: Беларуская навука.

Тегако Л.И. 1970. Антропологические данные к этногенезу белорусского народа (дерматоглифика и одонтология). Автореферат дисс. ... канд. истор. наук.

Тегако Л.И. 1989. Дерматоглифика населения Белоруссии: популяционные аспекты изменчивости. Минск: Наука и техника.

Тегако Л.И. 1990. Организующие структуры дерматоглифики и закономерности ее популяционной изменчивости (по материалам исследования населения Белоруссии). Автореферат дисс. ... доктора мед. наук.

Тегако Л.И., Кобылянский Е.Д. 2015. Дерматоглифика в современном научном познании человека. Минск: Белорусская наука.

Marfina O. 2015. The main directions of anthropological research in Belarus. International Journal of Anthropology. Vol. 30. N. 3-4: 145-153.

\section{DOPRINOS L. I. TEGAKO ANTROPOLOGIJI BELORUSIJE}

\author{
Tatyana Hurbo
}

Sažetak. L.I. Tegako je započela istraživanja iz oblasti antropologije sredinom 1960-ih. Predmet njenog naučnog interesovanja obuhvatao je odontologiju i dermatoglifiku. Više od 40 godina L.I. Tegako je bila permanentni rukovodilac grupe, a potom i celog antropološkog Departmana. Početkom 1970-ih Beloruski antropolozi započinju kompleksnu antropološku studiju odrasle populacije, iz različitih delova Republike Belorusije (antropometriju, antroposkopiju dermatoglifiku, krvne grupe). Sveobuhvatni pristup je postao baza za istraživanje antropogenetske varijabilnosti lokalnih populacija na teritoriji Belorusije. Grupa antropologa pod rukovodstvom L.I. Tegako je 1998. dobila državnu nagradu Republike Belorusije za obim radova na temu "Čovek i njegova biokulturna adaptacija". Tokom 2000-ih naučno interesovanje L.I. Tegako obuhvatalo je istraživanje korelacije između dermatoglifa i psihosomatskih karakteristika. Kao rezultat svoje akademske karijere, L.I. Tegako je publikovala 17 monografija, 6 priručnika, 11 brošura i 209 naučnih radova. Lidija Ivanovna je radila na vodećim Univerzitetima u zemlji; njenih 7 studenata je odbranilo doktorske disertacije. Od 1999 radila je kao profesor biologije. L.I. Tegako je zaslužna i za organizovanje brojnih antropoloških kongresa u Minsku. Pridavala je veliku pažnju međunarodnoj saradnji. Kao rezultat toga L.I. Tegako je zaslužna za uspostavljanje stabilnih naučnih i prijateljskih veza sa kolegama iz Srbije: Institut za istoriju Nacionalne akademije nauka Belorusije i Matica Srpska sklopili su partnerski sporazum o saradnji. To uključuje razmenu iskustava, naučni rad, i realizaciju zajedničkih projekata.

Ključne reči: L.I. Tegako, antropologija, Belorusija, dermatoglifika, odontologija, kompleksno istraživanje. 